\title{
Sciendo
}

\section{Apartment Ownership in a Condominium under Georgian Law}

\author{
Tamar Zarandia \\ Tamar Tatanashvili \\ Faculty of Law, \\ Ivane Javakhishvili Tbilisi State University \\ Chavchavadze Ave. 1, \\ Tbilisi 0128, Georgia \\ Email: tamar.zarandia@tsu.ge \\ Email: Tamar.tatanashvili@tsu.ge
}

\begin{abstract}
The ancient history of the concept of condominium and the particular attitude towards the right of ownership of an apartment has attracted worldwide recognition for this type of property. The concept of condominium is based on three components: (1) individual ownership of an apartment; (2) joint possession of common property of a plot of land and parts of a building; and (3) membership in an owners' association. An apartment in a condominium is an exception to the principle of superficies solo cedit in property law. In this case, the rights of ownership of owners of apartments in a condominium-the rights of ownership of a number of persons-are accumulated with regard to a plot of land. This article analyses, on the one hand, the peculiarities of apartment ownership in condominiums, Georgian legislation-which is the result of the reception of German civil law, and, on the other hand, the court practice developed on these issues in Georgian law.
\end{abstract}

Keywords: condominium, homeowners' association, individual ownership of an apartment, superficies solo cedit 


\section{General overview}

The concept of condominium is ancient and is known in almost all legal systems due to the special attitude towards the right to own a home. This led to the worldwide recognition of this type of property in spite of a persistent doctrinal antagonism of the followers of the traditional concept of property rights (cf. Van Der Merwe, 2015, p. 9).

Socio-economic conditions and housing shortages after World War I and, especially, World War II, forced the legislatures of European countries to pay special attention to the institution of apartment ownership (see also Rohan, 1966, p. 1323). Some countries regulated this issue in detail in a civil code, although most European countries adopted a special law (Zarandia, 2019, p. 374).

Georgian law is based on the values and approaches of the European law. It exists in its current form due to the fact that it was formed as a result of the reception of German law (Chanturia, 2001, p. 900). However, after signing the Association Agreement, Georgia continues to harmonise with the European law in the sphere of private law (see also Chanturia, 2018, p. 916)

In the process of reception of German law, out of the original 25 articles governing apartment ownership in a condominium, 23 articles were deleted from the Civil Code of Georgia (CCG) and a lex specialis Law of Georgia on Homeowners' Association came into force to govern the issue (Law of Georgia on Homeowners' Associations, 2007). In the Georgian legislation, the legal vision and categories related to a homeowners' association share the provisions of the German law on housing (BMJV, 1951).

The research utilises the method of general scientific and normative research, as well as the method of comparative legal research, to compare specific issues with the examples of the systems of other countries.

The purpose of the research is to analyse Georgian and European approaches, especially the German law regarding condominiums. The research aims to define the peculiarity of the principle of superficies solo cedit and, based on the legislative and judiciary practices in Georgia, the following issues: the status of an annex to an apartment, the issue of representation of a homeowners' association in the court, representation during litigation between the members of a homeowners' association, the issue of responsibility of the 
members of a homeowners' association in judiciary practice, the problem of the relationship between the invalidity of the minutes of the homeowners' association meeting and the legal interest and abuse of rights.

\section{The concept of condominium in European countries and the regulation of condominiums in Georgia}

Different types of condominiums are known in European countries: it can be a classic residential condominium or a commercial or industrial condominium where a multi-storey building is structured as a network of shops, cinemas, garages, warehouses, hotels, etc. A professional condominium is in which the owners can be members of a particular profession who are engaged in professional activities, for example, a group of physicians may use a condominium for a medical centre. Recently, resort condominiums became popular in Europe; these are located near amusement parks, mountain resorts and, being the property that has been structured in time, represent the latest trend in the right of resort-housing ownership (cf. Van Der Merwe, 2015, p. 55). It is becoming clear today that simple ownership rights alone cannot meet the interests of modern complex civil transactions. It is necessary to create mechanisms that allow property to be used in a way that maximises overall utility (see also Akkermans, 2018, p. 3).

Some countries have special laws in the field of housing (Germany and France), while other countries have adopted a separate code (see also Ninua, 2012 , p. 16). In German law, matters related to apartment ownership were regulated by a special law (cf. Weitnauer, 1951, p. 161).

Property rights concerning condominiums in Georgia were regulated by the Civil Code of Georgia at the time of the adoption of the Civil Code (Zoidze, 2005, p. 191, see also Uberi, 2004, p. 70) However, since 2007, the issue of apartment ownership in condominiums has been regulated by a special law (Law of Georgia on Homeowners' Association, 2007, see also Ninua, 2012, p. 16). It should be noted that the regulation of homeowners' association issues by the Civil Code caused differences of opinion among the members of the Civil Code Development Commission from the very beginning, as these norms were considered organisational norms (see also Zoidze, 2005, p. 163). Apartment ownership regulations are a set of practical rules to address everyday problems in condominiums. 


\section{Common ownership and individual ownership right to an apartment in Georgian law}

In Georgian law, common property in a condominium is considered a classic case of a common property (see Zoidze, 2005, p. 163). However, the owner of an apartment is primarily the exclusive owner of the individual apartment and the common property is the value related to his/her individual property. However, this reflection, which illustrates the connection of most individuals with the exclusive nature of property, does not allow us to ignore the growing importance of the collective aspects of property. The forms of common ownership themselves are different in Georgian law. The right of ownership of a legal entity itself, from a sociological point of view, can also be considered as the common ownership of group members over certain property (cf. Terré \& Simler, 2010, p. 432).

The Law of Georgia on Homeowners' Association defines the concepts of a condominium and an apartment in a condominium. In Georgian law, a condominium is a building that consists of more than two subjects of individual ownership (apartments), and an apartment in a condominium is a subject of individual ownership, which may be a set of adjacent (interconnected) premises united in one system or isolated premises (set of premises) (Zarandia, 2019, p. 376; see also Ross-Harrington, 2009, p. 191) used for residential or non-residential, including commercial, purposes (Law of Georgia on Homeowners' Associations, 2007, Art. 3, see also Paulick, 1952 , p. 432). Thus, the aforementioned regime is established when a specific building is legally divided into separate units and common property. The structure of the building/apartment/premises is important for this definition, and an apartment in a condominium is a certain set of rooms that makes it possible to run a household (cf. Wolf \& Wellenhofer, 2016, para. 2, note 15), or a space that can be used for commercial purposes.

The owner of the apartment considers himself/herself the exclusive owner of his/her own apartment and is only indirectly related to the common property. For him/her, the common property is the quota related to his individual property (cf. Terré \& Simler, 2010, p. 432). However, when purchasing an apartment, a person acquires ownership of an apartment, a share in the common property and becomes a member of the owners' association. Recognition of the existence of individual property rights on a separate apartment is an exception to the general principle of the Civil Code of Georgia, stating that essential constituent parts cannot be considered as objects of separate rights (CCG, Art. 150). 


\section{An apartment in a condominium and the principle of superficies solo cedit}

Following the adoption of European private law, one of the principles of Georgian property law is the principle of superficies solo cedit (see also Zarandia, 2019, p. 66), according to which the status of a building located on a plot of land is related to the status of the given plot of land, which ensures the legal unity of the plot and the building (see also Jickeli et al., 2004, para. 94, note 2 ).

The roots of this principle come from Roman law. Under Roman law, immovable property included not only a plot of land and subsoil, but also the goods on the surface of the earth created by the labour of another person or the owner, which was considered an artificial or natural part of the land and subject to the principle of inseparability of property created on the surface of the land from the plot of land (see also Garishvili \& Khoperia, 2013, p. 277).

Exceptions to the principle of superficies solo cedit are the cases of apartment ownership in condominiums (see Zoidze, 2003, p. 206) which according to the the legislation of Georgia and most European countries (including Germany) may be the objects of a separate right, must necessarily relate to an independent, separated and isolated apartment (cf. Wolf \& Wellenhofer, 2016 , para. 2, note 16). In fact, the rights of ownership of the owners of an apartment in a condominium - the rights of ownership of a number of persons-are accumulated concerning a parcel of land. Thus, if we reduce the dogmatic implication of the principle of superficies solo cedit to its actual meaning and return to the basic rules of attachment to property, the multifaceted concept of property rights may be formed (cf. Bouly, 2012, p. 43). Thus, it can be said that this principle is not observed everywhere to the maximum extent (see also Van Der Merwe, 2015, p. 23).

Under Article 193 of the Civil Code of Georgia, if a movable item is connected to a plot of land in such a way that it becomes an essential component of this plot of land, then the landowner becomes the owner of this property at the same time. Part II of Article 150 of the Civil Code assigns the buildings, premises and other land-related objects to the essential components of the land (CCG, 1997). In case of co-ownership of the main item, its essential component is also subject to the system of balancing rights (Decision AS-1653-1550-2012).

The principle of superficies solo cedit ensures legal certainty as it allows the potential purchaser of a plot of land to determine quite easily the items 
to which the agreement applies. However, in this way, the economic losses that may arise in the case of ownership of a plot of land and a building by different persons are avoided (see also Jickeli et al., 2004, para. 94, no. 3; Palandt \& Heinrichs, 2005, para. 94, note 1). Essential components of an item cannot be the subject of another person's exclusive rights (Zarandia, 2017, p. 6).

In a civil transaction, however, it is difficult to distinguish between essential and non-essential parts, in which case the approach established in a civil transaction or the judgment of an objective observer (third party) is crucial. The time of connection of items is important (cf. Wolf \& Wellenhofer, 2016, para. 1 , note 23$)$.

\section{The status of an annex to an apartment}

The issue of the legal status of an annex to an apartment has become important in the judiciary practice of Georgia. Therefore, it is important to consider the essential and non-essential components of an apartment. Essential components are parts of an item that cannot be separated from each other in such a way that they do not destroy one or more parts or change the nature and purpose of the item and do not cause it substantial damage (Criminal Code, Art. 150 I). Such items lose their individual status as a result of joining and becoming parts of one whole item (Knieper, 2015, p. 34). The same can be said about cases where separation is possible, but the costs involved are inadequately high. According to the Supreme Court of Georgia (Decision AS-820-872-2011), the essential component of an item is that which is purposefully related to it.

However, is an annex to an apartment an integral part of this apartment and should it be covered, for example, by a legal obligation related to an apartment? The Supreme Court of Georgia recognised an annex to a residential building as an essential component of the house. The court noted that an annex to a residential building could not be a separate object under civil law, which meant that the property rights to the house applied to its annexes (Decision AS-820-872-2011).

In addition, the legal status of a basement has become the subject of discussion in the Supreme Court of Georgia. According to the court, a basement in a condominium is not considered an essential component of 
the condominium but an object of a separate right (see also Decisions AS1653-1550-2012 and AS-355-641-04). This view is convincing because the connection of the basement with an individually owned apartment does not satisfy the preconditions established by the law for the essential component and does not create a substantive unity with the main item.

\section{The issue of representation of the homeowners' association in court}

The activities of a homeowners' association are led by the chairperson of the homeowners' association, who is elected for a definite term at the general meeting of the members of the homeowners' association by $2 / 3$ of the votes of the members of the homeowners' association (Law of Georgia on Homeowners' Associations, 2007; cf. Hansmann, 1991, p. 34). The chairperson of the homeowners' association shall appear in court on behalf of the association, but he/she shall not dispose of the common property of the association, shall not make a decision on the transfer, or reclaim, of the property under the possession of the association. The chairperson of a homeowners' association ensures the implementation of the decision of a meeting of the members of the association, but not authorised to file a lawsuit in the court on his/her own initiative. The request of the chairperson of the homeowners' association acquires a legal basis only in the presence of the decision of the meeting (Decision AS-1098-1029-2012).

The right to file a lawsuit due to the unlawful disposal of the common property of the members of a homeowners' association belongs to the homeowners' association itself, which participates in the legal relations on its own behalf (Law of Georgia on Homeowners' Association, 2007, Art. 14.2). In such a relationship, the Association shall be represented by the chairman or another person authorized to do so (Law of Georgia on Homeowners' Association, 2007, Art. 14.2), who shall be duly authorized by the general meeting of the homeowners' association.

In the legal relationship of the homeowners' association, when the dispute concerns not the activities of the association but the rights and obligations of the members, which are directed against each other, the chairperson cannot be considered a representative of the association. In this case, the essence and purpose of the legally regulated association of homeowners are decisive, which implies ensuring legal conditions for management, operation 
and development of the common property of the association members (Law of Georgia on Homeowners' Association, 2007, Art. 2).

The Court of Cassation clarified in one of the cases that the law does not entitle the chairperson of a homeowners' association to represent the members of the association in a court case involving individual premises transferred to them by the decision of the homeowners' association. In such a case, in the opinion of the court, the chairperson of the homeowners' association may represent the members of the association in court on a common basis, in particular, based on a power of attorney issued in compliance with the requirements of Civil Procedure Code (Civil Procedure Code, 1997, see also Decision AS-1073-1024-2013).

\section{Representation during litigation between the members of a homeowners' association and the issue of responsibility of the members of a homeowners' association in judiciary practice}

Common property is managed by the homeowners' association. The membership of the homeowners' association entitles the homeowners to participate in the management process of the homeowners' association (Law of Georgia on Homeowners' Association, 2007, Art. 26). According to the legislation, the homeowners' association is represented by the chairperson or another person authorised to do so. It is interesting to know whether the chairperson of the homeowners' association has the right to represent the association in court in a lawsuit filed by a member of the association against the association itself in connection with the imposition of an obligation to pay money. On this issue, the court clarified that the chairperson represents the homeowners' association in relation with third parties, although the legal relationship that the members of the association have with each other differs from the legal relationship that the association has with third parties. The imposition of leading the association activities implies the exercise of the rights of the members that are directed not towards each other but to achieve a common goal. The exercise of these rights may be imposed on one of the members of the homeowners' association, who has an obligation to perform them in good faith (to conduct common affairs). The chairperson of the homeowners' association may represent the members of the association in court on the basis of a power of attorney (Decision AS-298-285-2015). 
The membership of a homeowners' association stipulates certain obligations which limit the free will of the owners. Even the owner of a separate apartment can use the apartment in his individual ownership only in such a way that is compatible and acceptable to other co-owners and does not harm them (cf. Wolf \& Wellenhofer, 2016, para. 2, note 20). The owner is liable even if the apartment he/she owns has been handed over to other people for use. Apartment ownership in a condominium is closely linked to the issue of neighbourhood emissions, in which case the norms of neighbourhood law are also applied (cf. Zoidze, 2003, p. 210; see also Paulick, 1952, p. 432).

There are frequent cases when a member of a homeowners' association does not fulfil his/her obligation to the association. In such a case, the chairperson of the homeowners' association, in agreement with the meeting of the members of the homeowners' association, may register the debt of a member of the homeowners' association to the association as an obligation attached to a real estate item in the Public Registry (Real Estate Registry) (see also Law of Georgia on Homeowners' Association, 2007, Art. 14). Due to the breach of the obligation by the members of the homeowners' association, the persons that have to reimburse the damages caused to the members of the association are the members of the association who caused this damage and the liability is proportionate (unlike the liability of the members of the homeowners' association to third parties under Article 937.1 of the Criminal Code, which is a joint liability) (cf. Decision AS-298-285-2015). In case of alienation of individual property, the new owner, personally and as a joint debtor, shall be liable for the unfulfilled obligations of the (previous) member of the homeowners' association, related to the membership of the homeowners' association. In both Georgian and German law, the obligations of homeowners to each other result from a legal obligational relationship, the violation of which leads to claims for damages (cf. Zarandia, 2019, p. 385; Wolf \& Wellenhofer, 2016, para. 2, note 2).

Due to the fact that the homeowners' association is the owner of its own property and liable for the obligations of the association for this property before the creditor, the German Federal Court has recognised the homeowners' association as a legally capable entity sui generis (Wolf \& Wellenhofer, 2016, para. 2, note 25). 


\section{The problem of the relationship between the invalidity of the minutes of the meeting of the association and the legal interest}

The main governing body of a homeowners' association is the meeting of the members of the homeowners' association (Law of Georgia on Homeowners' Association, 2007, Art. 28; see also Rohan, 1966, p. 1326). Members of the association shall be notified in writing about convening a meeting of the association. Decisions are made in the form of minutes of the meeting. The approach of courts in relation to the appealed minutes of the meeting is interesting. In one of the cases, the court found that the disputed minutes of the meeting between members of the homeowners' association were approved in violation of the law and the property has not been transferred to the purchaser for ownership with the consent of all members of the homeowners' association. However, considering that, in this case, the object of the court reasoning is the requirement of deeming the disputed minutes of the meeting invalid, the court must first evaluate the existence of legitimate legal interests of the plaintiff. Since the invalidity of the minutes of the meeting belongs to the category of a declaratory action in its essence, the purpose of such lawsuits is not to assign a subjective right but eliminate the disputability of the right (Decision AS-1509-1429-2017, cf. also AS-664-6352016).

\section{Abuse of rights}

Without the consent of the homeowners' association, it is possible to develop an individual property owned by a member of the homeowners' association in a way that affects the common property of the members of the homeowners' association, but does not provide for an increase in the area of individual ownership and/or the emergence of a new individual property. The issue of abuse of rights by the members of a homeowners' association in this aspect is interesting. Generally, the restriction of private autonomy is manifested in the imposition of an obligation to exercise civil rights in good faith and the inadmissibility of abuse of rights. In both cases, the purpose of this restriction is to protect the freedom of others (Chanturia, 2017, p. 59).

For example, in one of the cases, the court noted that the legalisation of the building owned by a member of the homeowners' association would not 
affect the share of the homeowners' association's members in the common property of the association. In this case, the member of the association refused to give consent to legalisation. The court pointed out that good faith and legitimacy must be protected in the exercise of rights by the protected person. However, inadmissibility of abuse of property rights by a person is not only prohibited by law, but is also a moral duty of the owner (Zarandia \& Jugheli, 2012, p. 308). An abuse of the right is also equated with a situation where a person's inaction is not aimed at protecting the interests dictated by the need to exercise the right. In this case, as a result of assessing the facts of the case, we get a situation where, on the one hand, there is a right of a member of the homeowners' association to not give consent to the legalisation of a legally possessed building and, on the other hand, there is an interest of a person to legalise a building legally possessed by him/her, to which other members of the association agree and it is necessary for the protection of public order and the registration of property rights in the public register. The court considered that the exercise of the right was only determined by the intent to inflict damage on the other side and the action was not aimed at protecting the interests dictated by the need to exercise the right, which was equal to abuse of the right and therefore the party was instructed to give written notarised consent to legalise the building (Decision 2B/2595-12).

\section{Conclusion}

The approach of Georgian law to apartment ownership in condominiums is essentially similar to the values and principles provided by European legal systems, which is conditioned by the reception of German law in Georgian legislation. An apartment in a condominium is an exception to the general principle of superficies solo cedit. We should consider an annex to a residential house as an integral part of the latter, which means inter alia the application of the legal burden imposed on the main property to the annex as well. The basement, according to the approach established in Georgian law, is an object of separate rights.

The chairperson of a homeowners' association represents the association to third parties, although the legal relationship that the members of the association have with each other differs from the legal relationship that the association has with third parties. The right to file a lawsuit due to the unlawful disposal of the common property of the members of the 
homeowners' association belongs to the homeowners' association itself. The persons responsible for compensating the damage caused to a member by a breach of an obligation by members of the association are the members of the homeowners' association who caused the damage, and the liability is proportional. In a dispute between the members of the association, when the claim is related to the invalidity of the minutes of the meeting, the legal interest of the invalidity must be substantiated. In general, good faith and legitimacy must be protected in the exercise of rights by a protected member of the homeowners' association.

Tamar Zarandia, Doctor of Law, is associate professor at Ivane Javakhishvili Tbilisi State University. She is the dean of the Faculty of Law at Ivane Javakhishvili Tbilisi State University, chairperson of the Authorisation Council of Higher Educational Institutions. Dr. Zarandia has published over 50 research works and her research interests are civil law, property law, contract law and family law.

Tamar Tatanashvili is a PhD candidate at Ivane Javakhishvili Tbilisi State University. The topic of her thesis is The Ability to Be a Legal Subject of Persons in Need of Psychosocial Support. She is the editorin-chief of the legal journal TSU Law Review. She is also a member of Georgian Bar Association and the author of several legal articles.

\section{References}

Akkermans, B. (2018), 'Sustainable property law?' European Property Law Journal, vol. 7, no. 1, pp. 1-3. https://doi.org/10.1515/eplj-2018-0005

BMJV (1951), Gesetz über das 'Wohnungseigentum und das Dauerwohnrecht', 15.3.1951, Bundesgesetzblatt, Teil III, Gliederungsnummer 403-1, Bundesministerium der Justiz und für Verbraucherschutz. Retrieved from https://www.gesetze-im-internet.de/ [accessed 12 Jun 2020]

Bouly, S. (2012), 'The relation between the superficies and the ground... Back to basics,' in B. Akkermans \& E. Ramaekers (eds.) Property Law Perspectives, Cambridge: Intersentia \& Metro, pp. 21-44.

Chanturia, L. (2001), 'Das neue Zivilgesetzbuch Georgiens: Verhältnis zum deutschen Bürgerlichen Gesetzbuch,' in J. Basedow et al. (eds.) Aufbruch nach Europa, 75 Jahre Max-Planck Institut für Privatrecht, Tübingen: Mohr Siebeck, pp. 893-904. 
Chanturia, L. (2017), Commentary on the Civil Code [in Georgian], Chapter 1, Tbilisi.

Chanturia, L. (2018), 'Die Ausdehnung des Europäischen Privatrechts auf Drittstaaten am Beispiel Georgiens,' Zeitschrift für Europäisches Privatrecht (ZEuP), no. 4, pp. 916-935.

Civil Code of Georgia (1997), no. 786, Parliamentary Gazette, 31, 26.6.1997

Decision of Tbilisi Court of Appeals in case no. 2B/2595-12, 9.10.2012.

Decision of the Supreme Court of Georgia no. AS-1653-1550-2012, 15.4.2013.

Decision of the Supreme Court of Georgia no. AS-820-872-2011, 29.7.2011.

Decision of the Supreme Court of Georgia no. AS-355-641-04, 2.7.2004.

Decision of the Supreme Court of Georgia no. AS-1098-1029-2012, 3.12.2012.

Decision of the Supreme Court of Georgia no. AS-287-273-2016, 3.4.2017.

Decision of the Supreme Court of Georgia no. AS-1073-1024-2013, 10.3.2015.

Decision of the Supreme Court of Georgia no. AS-298-285-2015, 29.7.2016.

Decision of the Supreme Court of Georgia no. AS-298-285-2015, 29.7.2016.

Decision of the Supreme Court of Georgia no. AS-1509-1429-2017, 2.32018.

Decision of the Supreme Court of Georgia no. AS-664-635-2016, 2.3.2017.

Garishvili, M. \& Khoperia, M. (2013), Roman Law [in Georgian], Tbilisi: "Meridiani”.

Hansmann, H. (1991), 'Condominium and cooperative housing: transactional efficiency, tax subsidies, and tenure choice,' The Journal of Legal Studies, vol. 20, no. 1, pp. 25-71. https://doi.org/10.1086/467878

Jickeli, J. \& Stieper, M. (2004), §§90-103, in J. von Staudingers Kommentar zum Bürgerlichen Gesetzbuch, Buch I, 13. Auflage, Allgemeiner Teil §§90-133; §§154, 63 BeurkG, Berlin: Sellier - De Gruyter.

Knieper R. (2015), 'Die Kodifikatorische Suche nach den Subjekten, den Objekten und den Übertragungen des Eigentums,' in Eigentum und Rechtssicherheit: 'Wandel des Eigentumsbegriffs', Gemeinsame Konferenz der Staatlichen Ivane Javakhishvili Universität Tbilisi und des Max Planck Instituts für ausländisches und internationales Privastrecht, 5-6 November, Tbilisi, pp. 29-39.

Law of Georgia on 'Homeowners' Associations', no. 5277, 11.7.2007.

Mathieu, M. L. (2013), Droit civil: Les biens, Paris: Sirey.

Ninua, E. (2012), Homeowners Associations in Obligatory Legal Relationships [in Georgian], Tbilisi.

Palandt, O. et al. (2005), Kommentar zum BGB, 64., neu bearb. Aufl., Munich: Beck.

Paulick, H. (1952), 'Zur Dogmatik des Wohnungseigentums nach dem Wohnungseigentumsgesetz vom 15. März 1951,'Archiv Für Die Civilistische Praxis, vol. 152, no. 5, pp. 420-432. Retrieved from www.jstor.org/stable/40993357 [accessed 6 Jun 2020] 
Rohan, P. J. (1966), 'Cooperative housing: an appraisal of residential controls and enforcement procedures,' Stanford Law Review, vol. 18, no. 7, pp. 1323-338. https://doi.org/10.2307/1227173

Ross-Harrington, J. (2009), 'Property forms in tension: preference inefficiency, rent-seeking, and the problem of notice in the modern condominium,' Yale Law \& Policy Review, vol. 28, no. 1, pp. 187-221. Retrieved from www.jstor.org/ stable/27871291.[accessed 6 Jun 2020]

Terré, F. \& Simler, P. (2010), Droit civil: Les biens, 8-e édition, Paris: Dalloz.

Uberi, N. (2004), 'Homeowners' associations and its history' [in Georgian], Human and Constitution, no. 2, Tbilisi.

Van Der Merwe, C., ed. (2015), European Condominium Law (The Common Core of European Private Law), Cambridge: Cambridge University Press.

Weitnauer, H. (1951), 'Das Wohnungseigentumsgesetz', Juristen Zeitung, vol. 6, no. 6 , pp. $161-166$.

Wolf, M. \& Wellenhofer, M. (2016), Sachenrecht, 31. Auflage, Munich: C. H. Beck.

Zarandia, T. (2017), 'Component parts of property and appurtenance in Georgian property law,' Journal of Law, no. 2, pp. 5-12.

Zarandia, T. (2019), Property Law [in Georgian], 2nd revised edition, Tbilisi: Institute of Contemporary Private Law at the Faculty of Law Ivane Javakhishvili Tbilisi State University, "Meridiani”.

Zarandia, T. \& Jugheli, T. (2012), 'The exclusive nature of property rights and the misuse of property rights in Georgian and French law' [in Georgian], in Problems in Law: Roman Shengelia's 70th Anniversary Complete Works, Tbilisi: Grigol Robakidze University, pp. 297-313.

Zoidze, B. (2003), Georgian Property Law [in Georgian], Tbilisi: "Science".

Zoidze, B. (2005), Reception of European Private Law in Georgia [in Georgian], Tbilisi: Educational Center for Publishing Works. 